\title{
Comparison of Avifaunal Composition in a Natural and a Regenerating Forest: towards using Birds as Ecological Indicators
}

\author{
Thilina de Silva, K. B. Ranawana, Sumudu Fernando and Gajaba Ellepola* \\ Department of Zoology, University of Peradeniya, Peradeniya, Sri Lanka. \\ Accepted December 28, 2013
}

\begin{abstract}
Tropical forests have been extensively exploited and cleared for various reasons over the past years. Therefore, conservation emphasis has been given to protect natural forests and to assist regeneration of secondary forests. In the current study the composition and abundance of bird species in a natural forest (NF) and an adjacent regenerating forest (RF) in Maragamuwa, Naula in the Matale District were compared using a point count integrated line transect method. A clear variation was seen in the bird composition, diversity and evenness in both forest types and also during different time sessions of the day. In all the instances the values shown by the RF was greater than that of the NF and the species evenness showed high values for both forest types. The species composition showed no seasonal variation in NF throughout the study period while RF showed a seasonal variation. The endemicity of birds in the NF was higher than that of the RF. Hence, the current study shows that early successional forests support a rich bird diversity while the species richness of endemic bird species increases thereby enabling these measurements to be used as indicators in long term conservational practices.
\end{abstract}

Keywords: degradation, conservation, human assisted natural regeneration, Maragamuwa, vegetation structure

\section{INTRODUCTION}

Tropical forests are well known for their high biodiversity and support a rich wildlife communities. At least two-thirds of the world's animals and plants are found in tropical forests. However, many of these forests have been extensively exploited and cleared for timber and other land uses over the last century (Zakaria et al., 2005). Primary forests account for 36 percent of total forest area but have decreased by more than 40 million ha since 2000 . This is largely due to reclassification of primary forest to 'other naturally regenerated forests' because of selective logging or other human interventions (FAO, 2010). Most of the tropical forests are found in developing countries. The conservation of forests is a major challenge in these regions because of high human dependence on forest resources for livelihoods (Fernández-Juricic, 2004). Given the rapid population growth and ensuing increased demands for forest resources, this trend of declining forest cover is likely to continue in tropical regions (Beier et al., 2002; Sodhi et al., 2005). Throughout the tropics, deforestation due to logging, agricultural expansion and cattle ranching continues to cause a net decrease in forest cover annually (FAO, 2012). However, once the converted lands are exhausted and abandoned, they are allowed to regrow naturally
(Nepstad, et al., 1991). As a result, secondary forests make up an increasing percentage of forest cover. For some countries, secondary forests may soon be all that remains (Laurance and Bierregaard, 1997). While conservation emphasis has been on establishing reserves that protect mature forests, the importance of disturbed areas such as secondary forests for conservation of fauna has been increasingly recognized (Vandermeer and Perfecto, 1997; Chazdon, 2008).

Maragamuwa is a forested village situated in the drier borders of the intermediate zone in the Matale district. The natural vegetation type found in this region is most commonly dry mixed evergreen forest with scattered deciduous trees. The natural forest (NF) which borders our study site extends $47 \mathrm{~km}$ to Habarana. A part of this natural forest was cleared in early 1970s to make way for an Eucalyptus monoculture by the Ceylon Tobacco Company (CTC) to use as fuel to cure tobacco. Later, with the use of paddy husks as a substitute for Eucalyptus wood, the Eucalyptus monocultures were harvested and allowed to regenerate. Therefore, once the Eucalyptus harvesting was completed, human assisted natural regeneration practices were applied into these harvested plantation blocks and the secondary forest re-growth was facilitated

*Corresponding author's email: gajaba3@gmail.com 
from 2005 onwards (Reed et al., 2009). These forest blocks are referred to as the regenerating forest (RF) in this study.

Differences between bird species richness and assemblage composition in mature and secondary forests have previously been explained based on: 1) diversity of substrates, 2) abundance of food resources, 3) competitive species interactions, and 4) physical characteristics of the site (Wiens, 1989). The habitat selection by tropical birds is often correlated with food resources (Loiselle and Blake, 1991) and microhabitat features of nest sites (Borges and Stouffer, 1999). Based on this, a hypothesis was brought up in this study to test whether bird species richness is greater where food and cover resources (fruits, flowers, insects, and woody understory) are most abundant and variable.

Furthermore, for conservation work, the presence of certain bird species can be useful indicators for evaluating forest condition (Karr, 1982; Stotz et al., 1996). Good indicator species are unique or common species in a particular habitat that are easily detected and showed high sensitivity to degradation, fragmentation, or loss of a particular habitat (Stotz et al., 1996). In this study, above hypothesis was also tested by comparing the composition and abundance of bird species in two adjacent forest types, namely a natural forest and a regenerating forest in Maragamuwa, Naula, Sri Lanka.

\section{MATERIALS AND METHODS}

\section{Study site}

The study was carried out in the Biodiversity Conservation Site at Maragamuwa which comes under the intermediate zone. The area receives a mean annual rainfall of $1750-2000 \mathrm{~mm}$. The study site is about 60 hectares in extent and borders the dry mixed semi-evergreen natural forest from one side. This has made the site biologically very diverse. The site also shows high habitat heterogeneity, consisting of riverine forests, scrub jungles, grasslands and Eucalyptus plantations in addition to the regenerating forest which is in its early successional stages.

\section{Conservation status and statistical analyses}

Rank abundance curves or 'Whittaker plots' were used to display relative species abundance. It can also be used to visualize species richness and species evenness. Rank abundance curves overcome the shortcomings of biodiversity indices that cannot display the relative role of different variables played in their calculations (Kobayashi, 1983). A rank abundance curve was prepared for each of the two forest types. The curve is a two-dimensional chart with relative abundance on the $y$-axis and the abundance rank on the $x$-axis. The most abundant species is given rank one, the second most abundant is two and so on. Usually measured on a log scale, this is a measure of species abundance (e.g., the number of individuals) relative to the abundance of other species (Kobayashi, 1983).

Observations were made using a pair of binoculars $(8 \times 42$ Nikon - Monarch $)$. Data were recorded on DEFENDERS ${ }^{\circledR}$ data recording sheets, and the identification of birds was based on Harrison (1999) and Kotagama and Fernando (1994). Species nomenclature follows Rasmussen and Anderton (2005).

The Shannon Diversity Index $\left(H^{\prime}\right)$ was chosen as a composite measure of the bird diversity of each temporal session in each of the two forest types, because it is particularly useful for capturing both species richness and abundance. The Shannon Diversity index was used to measure diversity in categorical data. Shannon Evenness $(E)$ was used to see how evenly the species were distributed in each of the two forest types. Simpson's Diversity Index (D) was also calculated to compare any defaults that derive from the Shannon Diversity Index with regard to errors associated with the size of the sample.

The bird species recorded were categorized into groups such as rare (R), common (C), and very common (VC) (Kotagama and Fernando, 1994) with regard to their abundance. The distribution of these 'status classes' (R, C and VC) of the two forest types were determined and compared. The bird species were also categorized as endemic and migrant species.

\section{RESULTS}

A total of 136 species of birds belong to 59 families were observed in both forest types (Appendix 1). This included 13 species that are endemic to Sri Lanka as well as 17 winter migrants. Hundred and twenty seven species of birds belonging to 56 families were recorded from the RF which included 13 endemic species and 17 migratory species. In comparison, the NF hosted 117 bird species belonging to 55 families which included same number of endemic and migratory species. 
A clear variation is seen in the bird composition during different time sessions of the day (Figures 1 and 2). The $0600 \mathrm{~h}-0800 \mathrm{~h}$ is the time session where the bird activity was highest for both forest types NF and RF, with a mean number of species (richness) of 55.6 and 67.5, and a mean number of individuals (abundance) of 229.8 and 340.88 respectively. The species richness and abundance showed similar patterns in both forest types with the progression of the day, recording high values in $0600 \mathrm{~h}-0800 \mathrm{~h}$ session, falling in $0900 \mathrm{~h}-1100 \mathrm{~h}$, decreasing further in $1300 \mathrm{~h}-1500 \mathrm{~h}$ session and rising again in the $1600 \mathrm{~h}-1800 \mathrm{~h}$ (Figures 1 and 2).
Interestingly, in all time durations the values shown by the RF is greater than that of the NF.

The seasonal variation in species composition was more or less uniform in the natural forest during the study period (Fig. 3), with the number of individuals recorded varying between 693 and 793, for the months of July and January, respectively (Fig. 3). On the other hand, the regenerating forest showed more seasonal variation (Fig. 3), with the lowest number of individuals been recorded in August (930) and the highest in November (1245).

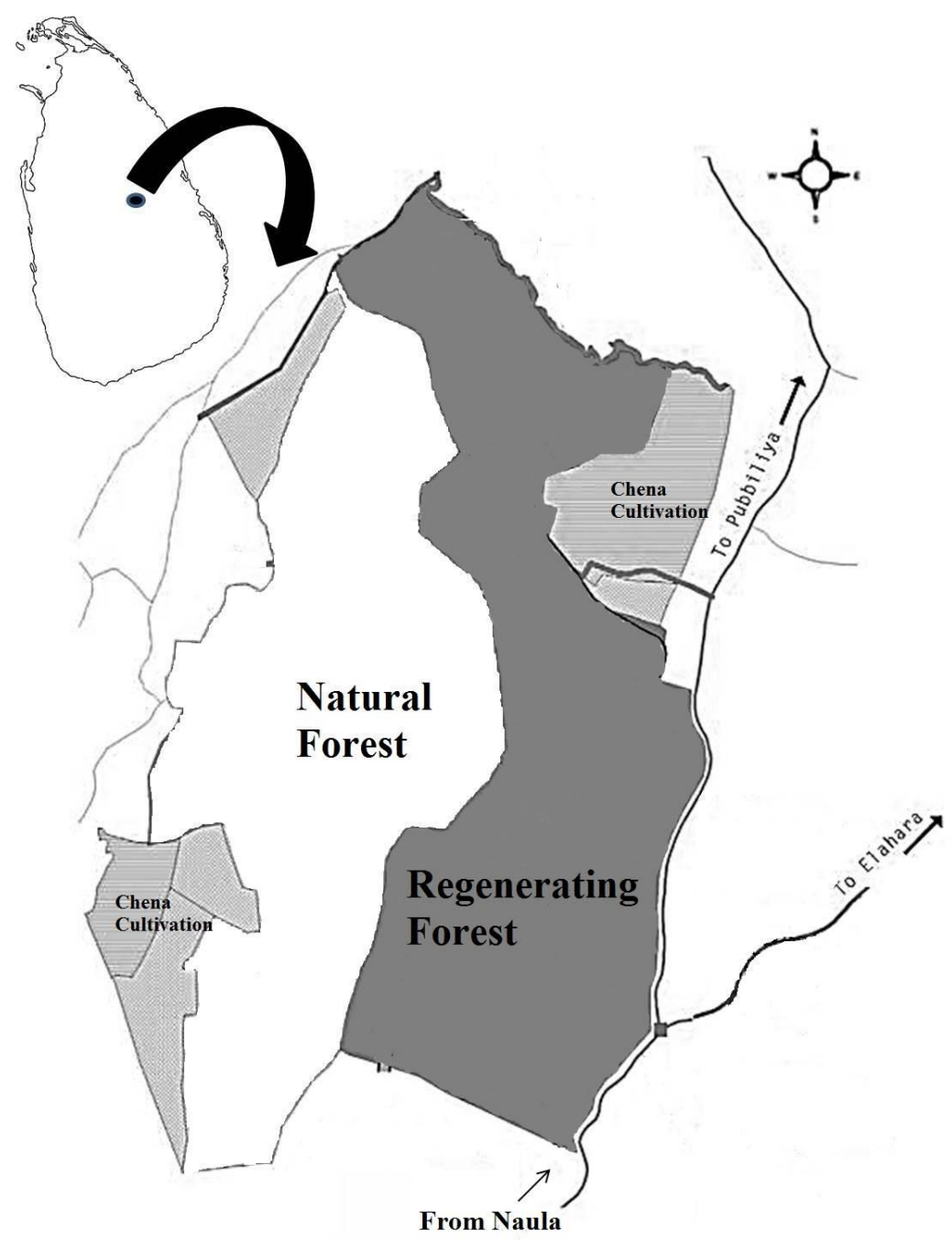

Figure 1. A map of Maragamuwa Biodiversity Conservation site in the Matale District of Sri Lanka. 
Number of Species Natural forest $\square$ Number of Species Regenerating forests
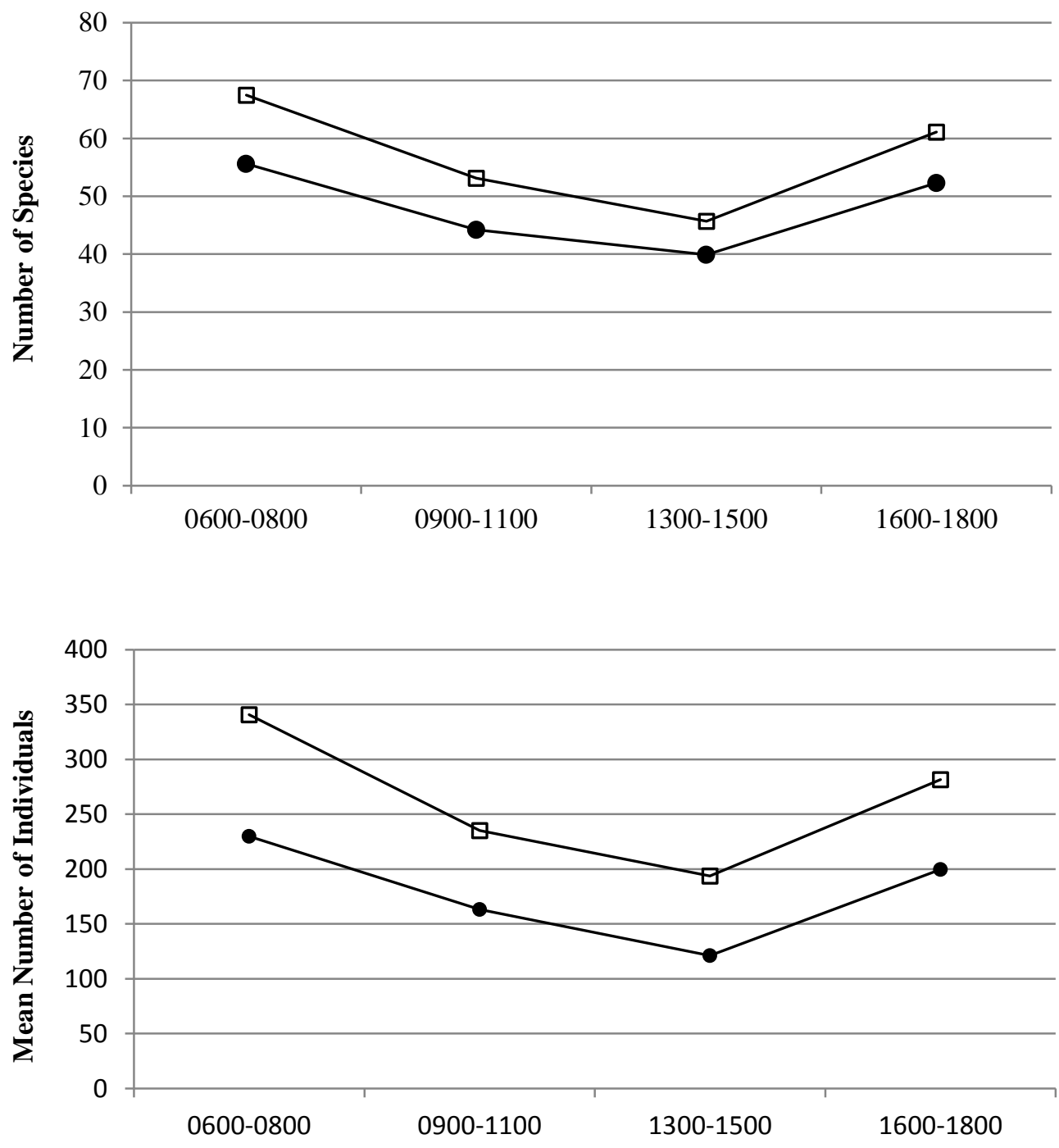

Time Session

Figure 2. (a) Average number of species and (b) average number of individuals per each time session in the Natural and the Regenerating Forests of Maragamuwa Consevation forest site

The overall highest values obtained for the Shannon Diversity and Simpson's Diversity Indices were higher $\left(\mathrm{H}^{\prime}=4.381\right.$ and $\left.\mathrm{D}=0.9138\right)$ in the natural forest, compared to that of the regenerating forest $\left(\mathrm{H}^{\prime}=4.275\right.$ and $\left.\mathrm{D}=0.8751\right)$. The diversity values were high in both forest types during the 0600h-0800h time session but comparatively higher in the regenerating forest. Diversity, however, was high in the regenerating forest during other time sessions recording higher index values.
The overall highest values obtained for the Shannon Diversity and Simpson's Diversity Indices were higher $\left(\mathrm{H}^{\prime}=4.381\right.$ and $\left.\mathrm{D}=0.9138\right)$ in the natural forest, compared to that of the regenerating forest $\left(\mathrm{H}^{\prime}=4.275\right.$ and $\left.\mathrm{D}=0.8751\right)$. The diversity values were high in both forest types during the $0600 \mathrm{~h}-0800 \mathrm{~h}$ time session but comparatively higher in the regenerating forest. Diversity, however, was high in the regenerating forest during other time sessions recording higher index values. 
Shannon evenness values indicated that the birds are more or less evenly distributed in both forest types, with values between 0.80 and 0.92 . The highest evenness values for both forest sites were obtained during the $0600 \mathrm{~h}-0800 \mathrm{~h}$ session, $(\mathrm{E}=$ 0.9199 and $\mathrm{E}=0.8824$ for $\mathrm{NF}$ and $\mathrm{RF}$ respectively). However, the evenness values were higher in NF during the morning session, and in RF higher evenness were recorded during the afternoon session.

From the total number of birds observed in the $\mathrm{NF}, 17$ are considered as rare species, 69 as common species and 28 as very common species (Harrison, 2011). In comparison, the RF had 15 rare species, 76 common and 33 very common species. At the level of individuals 343 rare, 3306 common and 2245 very common birds were observed in the NF whereas the numbers were 236, 3644 and 4375 for the RF in respective categories. As a percentage of the total number of birds in a given forest type, the NF had 6\% rare, $56 \%$ common and $38 \%$ very common individuals whereas the regenerating forest had $3 \%$ rare $44 \%$ common and $53 \%$ very common individuals (Figure 4).

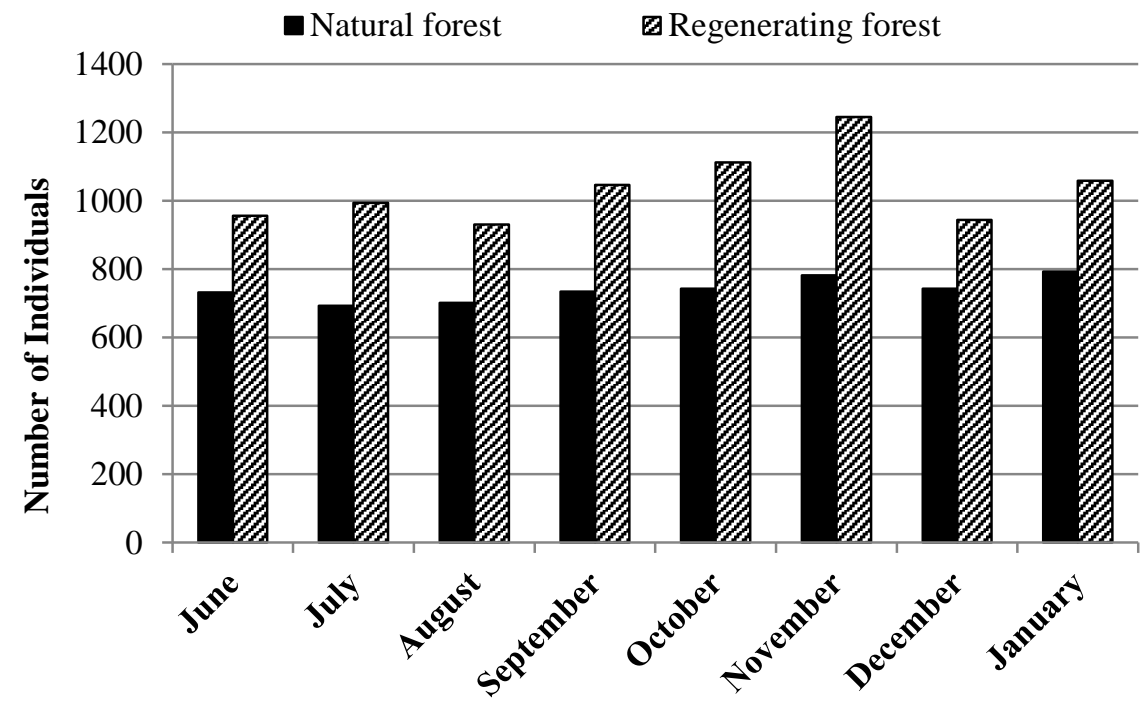

Figure 3. Total number of individuals recorded per day in the Natural and the Regenerating Forests in 2009 and 2010 in Maragamuwa Biodiversity Conservation site.

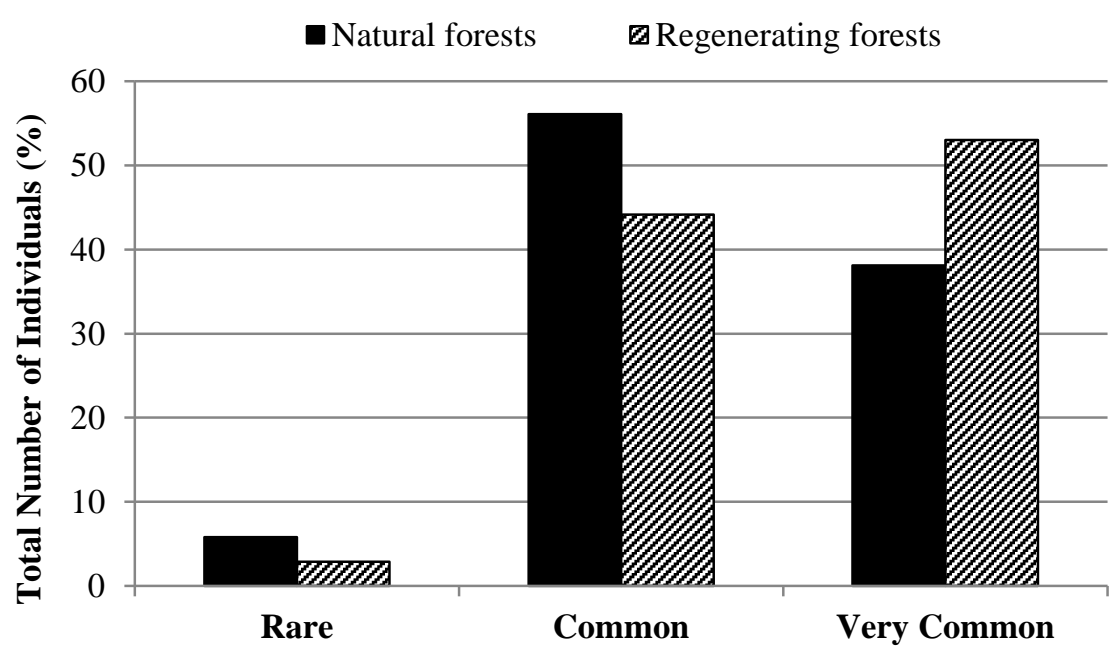

Figure 4. Distribution of birds in the NF and the RF with regards to the status; Rare (R), Common (C) and Very Common (VC) and abundance in Maragamuwa Biodiversity conservation site. 
Both forest types hosted 13 endemic bird species but in different proportions. The natural forest showed $18 \%$ endemism compared to $12 \%$ of the regenerating forests

\section{DISCUSSION}

With Sri Lanka's old growth forests having been reduced to less than $20 \%$ of their pre-colonial extent, increasing area of land, formerly heavily influenced by humans, are being allowed return to secondary forests and these areas have a higher conservational value and these emerging ecosystems in Sri Lanka harbour substantial endemic and threatened animal diversities (Pethiyagoda, 2012).

The study site consists of a mosaic of habitats, including grasslands, open grounds, dry-mixed semi-evergreen forests, scrub forests, riverine forests, Eucalyptus plantations, and aquatic habitats. It is known that habitat heterogeneity favors habitat specialists (through niche partitioning) and birds with broad niches as well (Surasinghe and de Alwis, 2010).

The study site hosted 136 species belonging to 59 families which included habitat generalists as well as habitat specialists. The intermediate zone which receives a mean annual rainfall between $1750 \mathrm{~mm}-2000 \mathrm{~mm}$ is known to support species of both dry and wet ecosystems (Henry, 1971). The presence of the endemic Yellow-fronted Barbet (Megalaima flavifrons) in the study site, a species usually restricted to the wet zone, as well as birds that are restricted to the dry lowlands, such as the Malabar Pied Hornbill (Anthracoceros coronatus), Hoopoe (Upupa epops) supports this assertion.

The regenerating forest patch was once a part of the adjacent natural forest, which has been later converted into a Eucalyptus plantation and presently undergoing assisted restoration. It is yet in its early successional stages. Substantial divergence in bird assemblages occurs in response to forest degradation (Nepstad et al., 1991) and fragmentation (Laurance and Bierregaard, 1997). Community structure often changes in response to disturbance (Nepstad et al., 1991) and when monitored over time, species richness, evenness, and abundance are useful measures of community resilience and stability (Magurran, 1988). The avian species composition in natural and regenerating forests differed more than expected given the small patch size of the RF compared to the larger NF. However, the two forest types differed substantially, accentuating the importance of habitat variables to explain the presence or absence of bird species. The vegetation structures were entirely different in the two forest types. The NF had old, large trees and offered more invertebrate food resources in the thick litter layer according to the observations. The RF contained more closely-spaced trees that are relatively young (3-5 y old). These structural differences among the two forest types seem to have considerable effect on the structure of their respective bird communities. According to Diaz et al. (2006), early successional forests support greater bird diversities compared to mature forests. The results of the present study are consistent with this conclusion. Thompson and Dessecker (1997) stated that as early successional forests become more mature, their capacity to support rich avifaunal diversities decreases drastically.

However, in the present study the natural forests harbor putatively more valuable species such as endemics and rare species compared to that in the regenerating forest. It seems that endemic bird species encounter difficulties in tolerating modified landscapes (Wijesinghe and Brook, 2005). This highlights the vulnerability of endemic species in forest conservation. Furthermore, species tolerant of such ecosystems, enjoy greater areas of occupancy, are less threatened than those that are not and this factor should be considered in the conservation assessment and planning process (Pethiyagoda, 2012).

\section{REFERENCES}

Beier, P., Drielen, M. V. and Kankam, B. O. (2002). Avifaunal collapse in West African forest fragments. Conservation Biology 16: 1097-1111.

Borges, S. H., and Stouffer, P. S. (1999). Bird communities in two types of anthropogenic successional vegetation in central Amazonia. Condor 101: 529-536.

Chazdon, R. L. (2008). Beyond deforestation: Restoring forests and ecosystem services on degraded lands. Science 320: 1458-1460.

Fernández-Juricic, E. (2004). Spatial and temporal analysis of the distribution of forest specialists in an urban-fragmented landscape (Madrid, Spain): implications for the local and regional bird conservation. Landscape and Urban Planning 69: 17-32. 
Food and Agricultural Organization. (2010). Global forest resources assessment 2010 main report. Food and Agriculture Organization of the United Nations, Rome. Chapter 2. Extent of forest resources. ISBN 978-92-5-106654-6. Pp 9-11

Food and Agriculture Organization. (2012). State of the world's forests. Food and Agriculture Organization of the United Nations, Rome. Chapter 2. ISBN 978-92-5-107292-9. Pp 8-22

Harrison, J. (2011). A Field Guide to the Birds of Sri Lanka. Oxford University Press, Oxford.

Henry, G. M. (1971). A Guide to the Birds of Ceylon. K. V. G. De Silva \& Sons. Kandy.

Karr, J. R. (1982). Avian extinction on Barro Colorado Island, Panama: a reassessment. American Naturalist 119: 220-239.

Kobayashi, S. (1983) The species-area relation for archipelago biotas: Islands as samples from a species pool. Researches on Population Ecology 25(2): 118-129.

Kotagama, S. W. and Fernando, P. (1994). A Field Guide to the Birds of Sri Lanka. The Wildlife Heritage Trust of Sri Lanka. Colombo.

Laurance, W. F. and Bierregaard, R. O. J. (1997). Tropical Forest Remnants: Ecology, Management, and Conservation of Fragmented Communities. University of Chicago Press, Chicago.

Loiselle, B. A. and Blake, J. G. (1991). Temporal variation in birds and fruits along an elevational gradient in Costa Rica. Ecology 72: 180-193.

Magurran, A. E. (1988). Ecological diversity and its measurement. Princeton University. Press, Princeton.

Myers, N., Mittermeier, R. A., Mittermeier, C. G., Da Fonseca, G., and Kent, J. (1992). Biodiversity hotspots for conservation priorities. Nature 403: 853-858.

Nepstad, D.C., Serrao, E. A. S., and Uhl, C. (1991). Recuperation of a degraded Amazonian landscape forest recovery and agricultural restoration. American Biologist 20: $248-255$.

Pethiyagoda, R. (2012). Biodiversity conservation in Sri Lanka's novel ecosystems, Ceylon Journal of Science (Bio. Sci.) 41(1), $1-10$.
Rasmussen, P. C. and Anderton, J. C. (2005). Birdsof South Asia, the Ripley guide.Smithsonian Institution and Lynx Edicions. Washington. U.S.A.

Reed, T., Ranawana, K. B and Nanayakkara, A. (2009). Methods tested and their costs to control regrowth of coppiced Eucalyptus camaldulensis in harvested plantations in Naula, Matale District, Sri Lanka. Ceylon Journal of Science (Bio Science). 38 (2): 7583.

Sodhi, N. S., Koh, L. P., Prawiradilaga, D. T., Putra, D. D., and Tan, T. H. T. (2005). Land use and conservation value for forest birds in central Sulawesi (Indonesia). Biological Conservation 122: 547-558.

Stotz, D. F., Fitzpatrick, J. W., Parker, T. A., and Moskovits, D. K. (1996). Neotropicalbirds: ecology and conservation. University of Chicago Press, Chicago.

Surasinghe, T. D. and De Alwis, C. (2010). Birds of Sabaragamuwa University Campus, Buttala, Sri Lanka. JoTT Communication 2(5): 876-888.

Thompson, F. R. and Dessecker, D. R. (1997). Management of early successional communities in central hardwood forests; with special emphasis on the ecology and management of Oaks, Ruffed grouse and forest song birds. US Department of Agriculture, Minnesota.

Vandermeer, J., and Perfecto, I. (1997). The agro ecosystem: A need for the conservation biologist's lens. Conservation Biology 11: 591-592.

Wijesinghe, M. R. and Brooke, M. de L. (2005). Impact of habitat disturbance on the distribution of endemic species of small mammals and birds in a tropical rain forest in Sri Lanka. Journal of Tropical Ecology 21, 661-668.

Wiens, J. A. (1989). Spatial scaling in ecology. Functional Ecology 3: 385-97.

Zakaria, M., Leong, P. C. and Yusuf, M. E. (2005). Comparison of species composition in three forest types; towards using birds as indicator of forest ecosystem health. Journal of Biological Sciences 5 (6): 734-737 
Appendix 1. Number of bird species and individuals (in parenthesis) by family observed in the natural and regenerating forests at Maragamuwa.

\begin{tabular}{|c|c|c|c|c|}
\hline \multirow[t]{2}{*}{ Family } & \multicolumn{2}{|c|}{ Natural Forest } & \multicolumn{2}{|c|}{ Regenerating Forest } \\
\hline & No. of species & $\begin{array}{l}\text { No. of } \\
\text { individuals }\end{array}$ & No. of species & $\begin{array}{l}\text { No. of } \\
\text { individuals }\end{array}$ \\
\hline Accipitridae & 9 & 246 & 8 & 103 \\
\hline Aegithinidae & 1 & 59 & 1 & 54 \\
\hline Alaudidae & 2 & 7 & 0 & 0 \\
\hline Alcedinidae & 1 & 2 & 2 & 28 \\
\hline Apodidae & 3 & 215 & 3 & 53 \\
\hline Artamidae & 1 & 8 & 0 & 0 \\
\hline Bucerotidae & 2 & 70 & 2 & 48 \\
\hline Campephagidae & 5 & 99 & 5 & 171 \\
\hline Caprimulgidae & 2 & 30 & 2 & 28 \\
\hline Charadriidae & 1 & 10 & 0 & 0 \\
\hline Columbidae & 6 & 572 & 4 & 289 \\
\hline Coraciidae & 1 & 43 & 1 & 6 \\
\hline Corvidae & 2 & 302 & 1 & 3 \\
\hline Cuculidae & 8 & 175 & 6 & 85 \\
\hline Halcyonidae & 2 & 214 & 1 & 59 \\
\hline Hemiprocnidae & 1 & 150 & 1 & 14 \\
\hline Hirundinidae & 2 & 224 & 2 & 17 \\
\hline Laniidae & 1 & 45 & 1 & 24 \\
\hline Megalaimidae & 4 & 540 & 4 & 627 \\
\hline Motacillidae & 4 & 75 & 2 & 34 \\
\hline Phasianidae & 2 & 89 & 2 & 119 \\
\hline Picidae & 5 & 142 & 5 & 165 \\
\hline Podargidae & 0 & 0 & 1 & 3 \\
\hline Prionopidae & 1 & 105 & 1 & 157 \\
\hline Psittacidae & 5 & 793 & 5 & 770 \\
\hline Pycnonotidae & 4 & 631 & 4 & 483 \\
\hline Rallidae & 0 & 0 & 1 & 2 \\
\hline Scolopacidae & 1 & 1 & 2 & 6 \\
\hline Strigidae & 4 & 18 & 5 & 30 \\
\hline Turnicidae & 1 & 18 & 1 & 3 \\
\hline Upupidae & 1 & 3 & 1 & 2 \\
\hline
\end{tabular}

